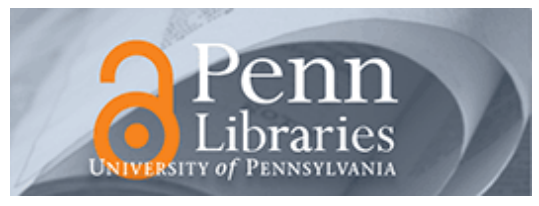

University of Pennsylvania

ScholarlyCommons

Marketing Papers

Wharton Faculty Research

1972

\title{
Role Conflict: Society's Dilemma with Excellence in Marketing
}

\section{J. Scott Armstrong \\ University of Pennsylvania, armstrong@wharton.upenn.edu}

Robert W. Nason

Follow this and additional works at: https://repository.upenn.edu/marketing_papers

Part of the Marketing Commons

\section{Recommended Citation}

Armstrong, J. S., \& Nason, R. W. (1972). Role Conflict: Society's Dilemma with Excellence in Marketing. Wharton Quarterly, 7 (1), 13-16. Retrieved from https://repository.upenn.edu/marketing_papers/235

This paper is posted at ScholarlyCommons. https://repository.upenn.edu/marketing_papers/235

For more information, please contact repository@pobox.upenn.edu. 


\title{
Role Conflict: Society's Dilemma with Excellence in Marketing
}

\author{
Abstract \\ In recent years, the American market system has come under increasing criticism from those it serves. \\ Many young people, radicals, members of minority groups and even middle-of-the-roaders are concerned \\ about such things as poor product quality, poor variety, unsafe products. and misleading advertising. \\ From almost any vantage point, flaws in the American economic system are visible. \\ Disciplines \\ Business | Marketing
}


Published in Wharton Quarterly, 7 (1), 1972, 13-16.

\title{
Role Conflict: Society's Dilemma with Excellence in Marketing
}

\author{
Robert W. Nason \\ J. Scott Armstrong
}

In recent years, the American market system has come under increasing criticism from those it serves. Many young people, radicals, members of minority groups and even middle-of-the-roaders are concerned about such things as poor product quality, poor variety, unsafe products. and misleading advertising. From almost any vantage point, flaws in the American economic system are visible.

The flaws are of such magnitude that many even question the overall value of the market system. For example, in a speech to the Sales Executives Club of New York, marketing researcher Daniel Yankelovich noted that his studies have shown that the public's confidence in business's ability to achieve a good balance between "profit seeking" and "service to the public" has declined sharply from a 56 per cent average in recent years through 1969 to 29 per cent in $1970 .{ }^{1}$

Despite the mounting criticism, marketing goes on as usual. Marketers tend to discard the criticisms as being exaggerated. Grey Matter, a publication of Grey Advertising, Inc., extols:

Among the millions of people engaged in production and distribution there are sure to be rascals who seek to prey on the public. The guts issues today are: should the whole business world be smeared because of some miscreants? And what does such tarring do to our economy? ${ }^{2}$

Similar pacification is offered by James M. Roche, recent Chairman of the General Motors Corporation:

The dull cloud of pessimism and distrust that some have cast over free enterprise . . makes it urgent that those of us who are in business, who have made business our career, who are justifiably proud of our profession, that we stand up and be counted. It is up to us to reaffirm our belief in free enterprise. ${ }^{3}$

The education of marketers generally assumes that the problems could be eliminated if we would just "try a little harder." Marketing textbooks usually devote their first chapter to the need for considering society as a whole but this chapter generally has no relationship to the rest of the book where the nature and scope of marketing decisions are discussed.

In this paper we express a point-of-view. It is our basic premise that it is not the free market which has failed; rather, it is the largely premeditated departures from the free market which have been the major source of the problems. Furthermore, we shall argue that the major pressure for these departures comes not from outside the system but from within. As Walt Kelly's Pogo once noted, "We have met the enemy and they is us."

The crux of the problem revolves about the role (or the set of prescribed behavior) for the marketing manager. The firm's definition of this role seems to be in conflict with the role as it should be defined to best meet the needs of society. As a result. the marketing manager whQ attempts to perform well in his role as a marketing manager could be doing overall harm to society. In short, there appears to. be a conflict between "excellence in marketing" and the "needs of society."

The conflict between the role of the marketing manager and the needs of society is discussed in the first section of the paper. The major concern of the paper is that this role conflict should be recognized. The second section

\footnotetext{
${ }^{1}$ Wall Street Journal (November 24, 1971), 14.

${ }^{2}$ Grey Matter, 42 (7), July 1971, 1.

${ }^{3}$ New York Times, April 11, 1971.
} 
provides a discussion of how marketing managers often respond t6this conflict when they strive for excellence under the current role definition. The third section of the paper provides a brief review of some of the more promising suggestions which have been made to deal with what society considers to be undesirable role behavior by marketing managers.

\section{Understanding Role Conflict}

The free market is widely acclaimed as the economic cornerstone of American society and it is closely tied to the ideals of freedom and individual choice. Marketing managers often make public statements about the value of a free market as do government officials. In this paper. we accept the ideology that the free market provides the best solution to the economic problem in the United States. That is, it seems to be the best way to satisfy the needs of those people in an affluent society. ${ }^{4}$

While a precise definition of the free market often leads to endless debate. there are certain elements which nearly everyone would agree to as being important to the effective operation of a market system. These include:

Free entry of producers

No collusion among producers

Useful information for consumers

Free choice by consumers

The need or the people in a society can be met more efficiently. then. when improvement is made in each of these four areas. ${ }^{5}$

The marketing manager is the chief intermediary between the producers and the consumer. It is the job or the marketing manager then to help in identifying the needs of consumers and to help in meeting these needs [ efficient manner. Since a free market is also helpful in this regard. it would seem that the marketing manager's rote should (from society's point of view) be designed to try to promote free entry, to avoid collusion, to provide useful information. and to ensure free -choice on the part of consumers.

However, the actual role definition enforces quite the opposite behavior because it is defined to serve predominantly one of the many interest groups in the firm-the stockholder. He is viewed as an agent of the stockholder and his role is to take actions to "maximize profits." In short. the role sub-optimizes from the point of view of society. The narrowness of this role definition should be apparent. For example, consider that about twothirds of the corporate stock in the U.S. is owned by about one percent of the adults. ${ }^{6}$

What happens then, when a marketing manager takes his role seriously? ${ }^{7}$ What happens when he strives for excellence in his attempt to maximize profits? It turns out that he is rewarded for actions which reduce the effectiveness of the free market. He is more successful when he is able to restrict entry of other produders. when he colludes with other producers, when he interferes with the flow of useful information to the consumers. and when he restricts free choice by the consumers.

In short, there is a conflict between the role of the marketing manager. as currently defined by the firm, and the role which would best contribute to the needs of the society. This conflict was documented in the electrical conspiracy case of 1961 which involved collusion to fix prices among GE. Westinghouse and 27 other firms. Judge

${ }^{4}$ More precisely, it satisfies the needs for those people with wealth. It does not, however, seem to do a good job of deciding how the wealth should be distributed. But that's another problem.

${ }^{5}$ It is possible to construct theoretical arguments where progress on these dimensions would lead to a reduction in welfare. Lipsey, R. G. and Lancaster. K. "The General Theory of Second Best," Review of Economic Studies, 24 (1956-7), 11-32.

${ }^{6}$ Lampman, Robert, The Share of Top Wealth-holders in National Wealth 1922-1956, National Bureau of Economic Research, Princeton. N.J.: Princeton University Press, 1962, 209.

${ }^{7}$ Some marketing managers do not live up to their role. They try to maximize their own welfare rather than to maximize profits. This simply compounds the negative effect on society. 
Ganey, at the time of sentencing the marketing executives. said "... I am convinced that in the great number of these defendants' cases, they were torn between conscience and approved corporate policy, with the rewarding objectives of promotion, comfortable security, and large salaries." 8

\section{Response to the Conflict}

If the marketing manager adopts the current role prescribed by the firm, i.e., to maximize profits, there are two possible strategies for "excellence." These may be referred to as the strategies of the Ox and the Fox. These are presented as "extreme" strategies. We do not wish to imply that all marketing managers pursue such strategies (although it seems that many do). The point is that the strategies of the Ox and the Fox are rational possibilities for those managers who believe that their role is to serve only the stockholders. ${ }^{9}$ An understanding of these strategies may help in isolating effective solutions.

The Ox attempts to increase profits regardless of society's rules and regulations. He accepts the role prescribed by the firm, the yoke as it were, and proceeds directly toward the firm's goal irrespective of legal or moral constraints Thus, he is willing to break the law whenever there is an advantage to do so. He would be willing to violate the law to restrict entry of other sellers (e.g., the classic case of Standard Oil where prices were lowered in certain areas to drive other producers into bankruptcy; ${ }^{10}$ to collude with other sellers (e.g., the electrical conspiracy case mentioned above); to interfere with the flow' of useful information (e.g., raise and misleading advertising such as Carter's Little Liver Pills which are now Carter's Little Pills since they have nothing to do with the liver); and to restrict the choice of consumers (e.g.. where the automobile manufacturers colluded to prevent the introduction of anti-pollution devices on automobiles). ${ }^{11}$

The Ox is moderately successful. His major problem is that he cannot always trust his fellow conspirators (for example. "cheating" on the collusive agreement was found in the 1960 electrical conspiracy case). Seldom, however, is the Ox prosecuted for violation of the law. The penalties imposed by society are very small, implying a "boys will be boys" attitude. And the Ox seems to convince himself that the violations of the law are for the benefit of society. Consider the statement by F. F. Loock. president of Allen-Bradley Co. of Milwaukee, after he had pleaded guilty in the electrical price conspiracy case:

"No one attending the gatherings (in the electrical controls industry) was so stupid he didn't know (the meetings) were in violation of the law. But it is the only way a business can be run. It is free enterprise." 12

The above feeling has persisted as indicated by the recent price fixing case of the American Radiator and Standard Sanitary Corporation. ${ }^{13}$ This case involved more severe fines and prison terms than in any other anti-trust case since the electrical conspiracy of 1960. Judge Rosenberg pointed out in his refusal to reduce the sentences of the executives. the lack of contrition on the part of the defendants. In fact, the defendants seemed to consider themselves to be the injured party rather than the public.

Unlike the Ox who is only concerned with enforcement and its severity, the Fox is careful to operate within the letter of the law. He attempts to find loopholes in existing laws. If that does not work, he tries to get the law changed. The position he takes might be something like the following:

The free market is a wonderful concept. Unfortunately, it sometimes leads to cut-throat competition and this is not only bad for business. but also for the consumer. In our particular situation (e.g.. steel. automobiles, education, air travel, mail delivery, milk delivery, cutting hair,

\footnotetext{
${ }^{8}$ Brooks, John, Business Adventures, New York: Bantam Books, 1969, 188.

${ }^{9}$ This is usually rationalized by saying that the market will protect the other groups affected by the firm.

${ }^{10}$ Tarbell, Ida M., The History of Standard Oil Company, New York: McClure. Phillips \& Co., 1904.

${ }^{11}$ Mintz, Morton and Cohen, Jerry S., America. Inc., New York: Dial, 1971, Ch 8.

${ }^{12}$ Wall Street Journal, January 10, 1961, 10.

${ }^{13}$ Journal of Marketing, October, 1971, 78-79.
} 
helping sick people), the consumer is not adequately protected by the market. We support Bill No. xxxx which is designed to help the consumer.

The Fox may also take action to prevent the passage of laws designed to help the free market (e.g., truth-inadvertising, truth-in-lending). If he is not successful in stopping passage of the law, he is often successful in rewriting the law "for the benefit of his consumers."

One of the most successful ways in which the Fox achieves his aims is to try to make the government and the public believe that his business is not a business at all - it is a "sport," "a community of scholars," a "non-profit endeavor," a "humanitarian service," or a "necessity for national defense."

Some of the more successful activities of the Fox include:

(1) Restricting entry of producers by the American Medical Association in limiting the number of doctors who may practice; by the Yellow Cab Company in restricting the number of taxis available; and by the oil industry with its tariffs and quotas. (The Texaco 1969 Nine Month Interim Report is not even bashful. "... Texaco has made its position clear. The domestic producing industry cannot compete on an economic basis with the large-volume low-cost oil produced in many foreign areas. Import controls must therefore be retained.")

(2) Collusion among producers by the football industry in their hiring of players; by stockbrokers in fixing commissions; and by the airline industry. The behavior of the American Pharmaceutical Association is a case in point. When the Osco Drug chain attempted to post its discount prices in stores which such posting was legal. the pharmaceutical Association mounted a massive legal. investigative, and pressure campaign principally through state pharmaceutical control boards. ${ }^{14}$

(3) Poor and misleading information may continue thanks to the efforts of industry to delay or to emasculate the truth-in-lending. truth-in-packaging. and truth-in-advertising laws. Further, for some professions advertising is deemed "unprofessional" or "unethical." Restriction of information surfaces in other ways. For example, gas station price signs in Rochester, N.Y. cannot be read from the street due to a city ordinance which limits the size of the numerals which can be used.

(4) Forced or limited choice by consumers for the space program, for elementary education, for telephones, for highways. for mail service. and for welfare programs.

\section{Some Possible Solutions}

This section briefly reviews some of the more promising solutions which have been suggested for dealing with the problems created by role conflict in marketing. Recognizing that the Ox and the Fox attempt to introduce imperfections into the market, how can these strategies he countered?

Ox-Stoppers: One basic philosophy behind dealing with the strategy of the Ox is to apply punishment. It has been suggested, for example, that the marketing manager be held personally responsible for malpractice. Injured parties could then take legal action against the manager as well as against the company. Should managers be able to purchase malpractice insurance at company expense?

Another suggestion along the lines of punishment has been to make the firm responsible for the performance of its products. The legal system has been moving steadily in this direction. Of particular note is the fact that the value of "privity" as a defense has been greatly reduced. That is, the producer cannot avoid responsibility simply because he did not sell directly to the injured party. This is true for all but eight states in the U.S. ${ }^{15}$

Also, producers cannot rely upon a defense based upon "negligence." That is, it is no longer enough to say that "he tried his best" and is therefore free of blame. The trend is towards holding the firm responsible for insuring that

${ }_{14}$ Consumers Reports, 27 (3), March 1972, 134-140.

15 Presser, William L., Handbook of the Law of Torts, St. Paul, MN: West Publishing Co., 655. 
its products and services perform satisfactorily. Class-action suits by consumers would provide an extremely effective way to hold the producer accountable for its product in situations where the cost of a lawsuit would be prohibitive for an individual consumer. ${ }^{16}$ There is currently much interest in enabling legislation which would help to make class action suits effective. They are currently not effective for marketing problems. (Rheingold says he is not aware of any class action suits in product liability. ${ }^{17}$ )

The effectiveness of the punishment philosophy could be improved also by an increase in vigilance by people within the firm. Everyone in the firm should be concerned about stopping illegal and unethical activities. The marketing manager is in an especially advantageous position to observe illegal and unethical activities. If unethical actions not in society's interest are observed, the individual could try to remedy the situation within the firm. If that fails, he could publicly "blow the whistle." The power of the whistle blower is surprisingly large. Some examples ${ }^{18}$ include Jacqueline Verrett, a biochemist with the Food and Drug Administration who angered her superiors by appearing on television to warn that cyclamates might cause birth defects; A. Dale Console, a former medical director of E. R. Squibb \& Sons, who testified before congressional committees about allegedly corrupt practices in the drug industry; John Gofman and Arthur Tamplin, two scientists employed at an Atomic Energy Commission laboratory. who have charged that existing radiation standards will allow thousands of needless deaths; William I. Steiglitz, who resigned as engineering consultant to the National Traffic Safety Agency because he considered safety standards "totally inadequate"; A. Ernest Fitzgerald; who lost his job as an Air Force efficiency expert after he disclosed cost overruns on the C-5A jet transport to a Senate Committee; Ralph Stein, a former Army intelligence specialist who reported the extent of Army surveillance of civilians; and Edward A. Gregory, a General Motors inspector who complained about faulty exhaust systems in Chevrolets for more than three years before the company finally recalled some 2.4 million vehicles to fix the problem. It should be noted that false exposure can damage innocent firms and individuals but this is a risk which coexists with more accurate information and the freedom of speech.

The big problem with the whistle-blower is that his commitment to society is likely to cost him and his family severe hardship. He gets to make only one major contribution since the behavior which he is protesting is usually sanctioned by the organization. Baumhardt ${ }^{19}$ surveyed executives and concluded from his study that the behavior of one's superior was the most important cause of unethical decisions within the firm.

An example of what happens to the whistle-blower is provided by the case of Henry Durham. an executive for Lockheed For a number of years, he attempted to resolve a number of billing and management irregularities associated with the production of the C-5A aircraft internally within the company. However. it was not until the futility of this effort was obvious through snubs, demotions, and transfers that he took the matter to Senator Proxmire. This action invoked the wrath of his company, his church, and his town. ${ }^{20}$

A recent innovation for this country may help to prolong the life of the whistle-blower. This is the establishment of the office of "ombudsman." The ombudsman represents all interest groups. He is outside of the formal organization and does not report to the president or to the board of directors. He works on a fixed-term contract and his contract derives its power from the joint consent of at! interest groups. ${ }^{21}$ The ombudsman is in a position to follow up on unlawful or unethical actions which are being taken by a firm or by an industry. The identity of the watchdog can be protected much as the shop steward protects the employee in labor complaints. Ralph Nader has supported an organization whose function is similar to that of the ombudsman. This organization will handle problems for any industry. ${ }^{22}$

\footnotetext{
${ }^{16}$ Congressional Quarterly, 38 (March 13, 1970), 747-750.

${ }^{17}$ Rheingold. Paul D, "Problems in Multiple Party Litigation." in Selma Arnold (ed.) Products Liability, New York City: Practicing Law Institute, 1971, 171.

18 Boffey, Philip, "Nader and the Scientists: A Call for Responsibility," Science, February 12,1971, 549-551.

19 Baumhardt, Raymond C., "How Ethical Are Businessmen?" Harvard Business Review, 39 (July-August 1961), 156.

${ }^{20}$ Knoll, Edwin, "The Education of Henry Durham,” The Progressive, January 1972, 19-24.

${ }^{21}$ The term "ombudsman" has been inappropriately used in the public relations efforts of some firms (e.g., Chrysler Corporation) to apply to an "assistant-to-the-president." Gross, Edwin J., "Needed: Consumer Ombudsman," Business and Society, 8 (Autumn 1966), 22-27.

${ }^{22}$ The Clearinghouse for Professional Responsibility, P.O, Box 486, Washington, D.C., 20044.
} 
The above ideas represent only a partial listing of ways in which society can stop the Ox. All of these counter forces are to some degree currently being used and have the advantage of not requiring major institutional changes. The use of these counter forces seems to be growing.

Re-orienting the Fox: Rather than finding ways to stop the Fox, it seems more fruitful to try to re-orient his goal. In other words. an effort could be made to change the rewards rather than to use punishment.

In the early 1930's, there was much discussion over the role of the manager - e.g., see the exchange between Berle ${ }^{23}$ and Dodd. ${ }^{24}$ Berle claimed that the manager is and should be held responsible only to the stockholder. Dodd, on the other hand, suggested that perhaps the law should return to the original notion that the manager is responsible to all of the stakeholders in the firm - i.e., to the employees, stockholders, consumers, creditors, suppliers, and local community. ${ }^{25}$ Though there will be conflicts between the groups. on balance, such a change would bring the role of the marketing manager more into agreement with the role which is oriented towards the needs of society. Thus, there would be less pressure for the manager to use the strategy of the Fox.

There has been little progress since the 1930's toward the stakeholder role. However, there seems to have been a recent revival of interest. An organization known as the Project on Corporate Responsibility was successful in getting a proposal before the General Motors stockholders which would have placed representatives of various interest groups on the board of directors. While this proposal lost by a substantial margin, it did receive much favorable interest among the general public. And in 1972, the Banking Committee of the U.S. House of Representatives was examining the possibility of "legally mandated standards for effective representation on corporate boards of stockholder, consumer. general public. and other interests. ${ }^{, 26}$ Such representation is a step in the right direction but it must be recognized that current boards are often weak.

A related proposal which might also contribute to changing the role of the marketing manager is that firms should develop a system for "social accounting." This would involve an attempt to objectively measure the impact of the firm not only upon its stockholders but also upon the other stakeholders in the firm. Social accounting would be useful in helping to focus more attention on those non-financial goals of the firm. It would give mere attention to the concerns of the various stakeholders. While social accounting is not a new idea (a discussion can be found in ${ }^{27}$ ), it is one which has been receiving a fair amount of attention recently.

Certainly there are other suggestions which might help to improve the effectiveness of the marketing manager. However. we feel that the related ideas of a reorientation toward the stakeholders' role and the use of social accounting are especially worth of further consideration. ${ }^{28}$

\section{Conclusions}

The most important point in the paper is that there is a conflict between the role of the marketing manager as currently defined by most firms and the role which would seem most beneficial to society. We think that the society

${ }^{23}$ Berle. A. A.. Jr., "Corporate Powers As Powers in Trust." Harvard Law Review, 44 (1931). 1049-1074. Also, "For Whom Corporate Managers Are Trustees," Harvard Law Review, 45 (1932), 1365-1372.

${ }^{24}$ Dodd, E. Merrick, Jr., "For Whom Are Corporate Managers Trustees?” Harvard Law Review, 45 (1932), 11451163. Also, "Is Effective Enforcement of the Fiduciary Duties of Corporate Managers Practicable?" University of Chicago Law Review, 2 (1935).

${ }^{25}$ Berle has conceded that Dodd won the argument. He feels that managers are not limited to working toward maximum profits. Rather they are recognized in law as "administrators of a community system." Berle, A. A. Jr., "Foreword," in Edward S. Mason (ed.), The Corporation in Modern Society, New York: Antheneurn. 1969, xxi.

${ }^{26}$ Wall Street Journal, January 3, 1972, 4.

${ }^{27}$ Bowen, Howard R., Social Responsibilities of the Businessman, New York: Harper \& Brothers, 1953, 155.

${ }^{28}$ We are, for example, currently involved in some role playing experiments to determine what effects these changes would have on decision making within the firm: Armstrong, J. Scott and Majoros. Walter A., "Marketing Decisions and Social Responsibility," paper delivered at the Institute of Management Sciences Meetings, Houston, Texas (April 1972). 
would be served more effectively if the marketing manager were punished rather than rewarded for actions which sabotage the free market. Even better, it would seem useful to reorient the role of the marketing manager so that he is rewarded for actions which improve the operation of the market - actions which would promote free entry of other producers. reduce collusion among producers. promote the flow of useful information to consumers, and increase the freedom of choice by consumers. Until this role conflict is recognized. there will remain a dilemma between excellence in marketing and the needs of society. 